\title{
MISCELLANEOUS NOTES ON THAI GRAMINEAE
}

\author{
J.F. VELDKAMP \\ Nationaal Herbarium Nederland, Universiteit Leiden branch, \\ P.O. Box 9514, 2300 RA Leiden, The Netherlands \\ e-mail: veldkamp@nhn.leidenuniv.nl
}

\section{SUMMARY}

In recent collections of herbaceous grasses from Thailand some novelties were detected: Eremochloa maxwellii Veldk. and Parahyparrhenia laegaardii Veldk. New records for Thailand are: Eragrostis tenuifolia (Hochst.) Steud., Eulalia tetraseta Ohwi, Germainia thorelii A. Camus, Sporobolus tenuissimus (Schrank) Kuntze. A second collection after the type was made of Germainia pilosa Chai-Anan.

Key words: Eragrostis, Eremochloa, Eulalia, Germainia, Parahyparrhenia, Sporobolus, Gramineae, Thailand.

\section{INTRODUCTION}

Recently a few hundred grass collections collected in various parts of Thailand under the supervision of Dr. H.-J. Esser (M), Dr. S. Laegaard (AAU) and Dr. W.J.J.O. de Wilde \& Dr. B.E.E. de Wilde-Duyfjes (L) were presented for identification.

There are some very interesting localities especially in Ubon Ratchathani, for among the collections there were two species new for Thailand, previously only known from their types, and two that seem not to have been described at all. Where rarities occur, others may well be expected.

A report on new findings of Tripogon thorelii A. Camus, also only known from the type, but now known from Sisaket and Ubon Ratchathani is printed in this journal as well (Veldkamp \& Phillips, 2003).

Elsewhere some new introductions were discovered: Eragrostis tenuifolia (Hochst.) Steud., a noxious weed, and S. tenuissimus (Schrank) Kuntze, which at least in Malesia appears to be fairly widespread now.

\section{Eragrostis tenuifolia (A. Rich.) Steud.}

Eragrostis tenuifolia (A. Rich.) Steud. (1854) 268; Veldk. (2002) 187. - Poa tenuifolia A. Rich. (1851) 425. - Lectotype: Schimper 92 (holo P; K, L, WAG), designated by S.M. Phillips (1995: 122).

Tufted (long-living) annuals. Culms erect or geniculate, then with shoots and roots at the lower nodes, branching intra-vaginally at base, $0.5-0.8 \mathrm{~m}$ long, eglandular. Sheath collar pilose. Ligule a row of c. $0.25 \mathrm{~mm}$ long hairs. Blades $6-22 \mathrm{~cm}$ by $0.5-2 \mathrm{~mm}$. 
Panicles lax, $10.5-20$ by $4.5-9 \mathrm{~cm}$, axils pilose, branches erecto-patent, solitary, stiff, scaberulous, the lowermost 5-8 cm long, naked in the lower $0.25-0.3$ th. Pedicels 3.5-12 mm long, longer than the spikelets. Spikelets laterally compressed, disarticulating from the base upward, rhachilla persistent, $6.5-12$ by $2.25-2.75 \mathrm{~mm}$. Glumes unequal, acute, 0-nerved; lower glume $0.5-0.75 \mathrm{~mm}$ long, $0.2-0.3$ times as long as first lemma; upper glume 0.75-1.25 mm long. Lemmas 2.2-2.5 mm long, acuminate. Paleas persistent, keels scaberulous. Anthers 3,0.4-0.6 mm long, 0.19-0.27 times as long as the lemma. Caryopsis ellipsoid, strongly laterally flattened, dorsally grooved, 1-1.25 mm long, pericarp smooth, dark tea-coloured. $2 \mathrm{n}=20,40$.

Distribution - Tropical Africa, Madagascar, Sri Lanka, India to Vietnam, introduced elsewhere, e.g. N Thailand: Chiang Mai (Laegaard et al. 21655 (L; AAU, QBG)).

Habitat - Weed of roadsides, disturbed places, abandoned gardens, etc., $675 \mathrm{~m}$ altitude.

Uses - Eaten by cattle, but resistant to efficient mowing and difficult to pull up by hand, often a noxious weed along roadsides, etc.

Vernacular name - Elastic grass.

Notes - Flowers cleistogamous, anthers ejected by or glued to the ripening fruit.

Spikelets occasionally smutted by Bipolaris spec.

Easily recognizable by the tufts of hairs in the axils of the panicle branches, the fairly large, dark, jagged spikelets with a relatively short lower glume, and the very flat, dorsally grooved caryopses.

\section{Eremochloa maxwellii Veldk., spec. nov.}

A congeneribus omnibus differt ut videtur in characterum combinatione: cataphylla glabra, lamina gradatim acuta acumine acuto, articuli glabri, spiculae ellipticae, glumae inferioris alis apicalibus minutis (viridibus) acumine truncato, setae teretae longissimae $2-3 \mathrm{~mm}$ longae glumae latitudine plus minusve ad multo longiores, gluma superior secus margines et in medio parte inferiore 0.67 carinata. Floris inferioris antherae ca. $1.9 \mathrm{~mm}$ longae. Spiculae pedicellatae subulatae 1-1.2 mm longae. - Typus: Laegaard et al. 21811 (holo AAU).

Rhizome slender. Cataphylls glabrous. Culms c. $0.8 \mathrm{~m}$ long, branching extra-vaginally at base, basal internodes hollow, glabrous. Culm nodes glabrous. Sheaths glabrous. Ligule collar-shaped, c. $1 \mathrm{~mm}$ long, glabrous. Contra-ligule absent. Blades flat to folded, 6-15 cm by c. $3 \mathrm{~mm}$, acute, acumen acute, glabrous, margins glabrous. Racemes solitary, straight, 5-10 cm long. Joints 3-3.5 mm long, 0.6-0.65 times as long as the sessile spikelet, glabrous. Spikelets elliptic, $5-5.5$ by $1.7-2 \mathrm{~mm}$. Lower glume glabrous, 6- or 7-nerved, nerves distally with transverse veinlets, apex with small green apical wings, acumen truncate, setae straight, terete, the longest $2-3 \mathrm{~mm}$ long, longer to much longer than the width of the glume. Upper glume 4.8-5 mm long, keeled in the middle in lower 0.67 th and along the margins, glabrous. Anthers in lower floret 3 , c. $1.9 \mathrm{~mm}$ long (of upper floret not seen). Pedicel oblique-obovoid, 3.5-4.3 mm long, $0.7-0.9$ times as long as the sessile spikelet. Pedicelled spikelet reduced to a $1-1.2$ mm long subule.

Distribution - Only known from the type: E Thailand, Ubon Ratchathani, km 36 on road 217 E of Warin Chamrap.

Habitat - Secondary grassland, c. 125 m altitude. 
Notes - Named for Mr. J.F. Maxwell, Chiang Mai, renowned collector and connoisseur of the Thai flora.

I have seen no clearly extra-vaginal shoots, but the presence of cataphylls suggest their presence, as in the other congeners.

There are 8 (out of 11) species in Thailand (Buitenhuis \& Veldkamp, 2001). This new one is most similar to E. bimaculata Hack. and E. ciliaris (L.) Merr.

1a. Lower glume apex with small apical wings. Pedicelled spikelet present . . . . . 2

b. Lower glume apex without apical wings. Pedicelled spikelet absent. - Ligule ciliolate. Blades obtuse. Joints at base with a ring of short hairs. Lower glume acumen acute, setae flattened at base, the longest $1-5 \mathrm{~mm}$ long, much longer than the width of the glume . . . . . . . . . . . . . . . . . . . . E. .

2a. Ligule ciliolate. Blades obtuse. Joints at base with a ring of short hairs. Lower glume acumen acute, setae flattened at base, the longest $0.6-1.5 \mathrm{~mm}$ long, shorter to much shorter than the width of the glume ........... E. bimaculata

b. Ligule glabrous. Blades gradually acute. Joints glabrous. Lower glume acumen truncate, setae terete, the longest 2-3 mm long, longer to much longer than the width of the glume $\ldots \ldots \ldots \ldots \ldots \ldots \ldots \ldots \ldots \ldots \ldots \ldots \ldots \ldots$. maxwellii

\section{Eulalia tetraseta Ohwi}

Eulalia tetraseta Ohwi (1967) 138. - Type: T. Kira et al. 148 (holo KYO; OSA).

Tufted perennial. Culms 0.4-0.7 m tall, slender, somewhat stiff, 4- or 5-noded, base hardly thickened, nodes and base of culm sheaths white pilose, otherwise glabrous. Ligule c. $0.2 \mathrm{~mm}$ high, truncate, hyaline, glabrous. Basal sheaths smooth, somewhat compressed, 4-11 cm long, long pilose (sometimes sparsely so); blades linear, convolute, $10-30 \mathrm{~cm}$ by up to $1.5 \mathrm{~mm}$ ( $3 \mathrm{~mm}$ when flattened), somewhat stiff, above hardly striate sparsely long white pilose, below striate, smooth; culm sheaths terete, $8-10 \mathrm{~cm}$ long, smooth; blades linear-subulate, erect, 1-11 cm long. Raceme solitary, 3-11.5 cm long, slender, laxly many-spikeled, purplish, or greenish white; joints slender, c. 0.75 times as long as the sessile spikelet, compressed, margin long white ciliate. Sessile spikelet 4.5-5.5 mm long (incl. c. $1 \mathrm{~mm}$ long callus). Lower glume lanceolate, shiny, dorsally narrowly deeply grooved, groove densely white pilose, margin obtuse, white ciliate, nerves absent, apex bilobed, lobes with a slender arista 1.25-2 times as long as the glume; upper glume as long as the lower, boat-shaped, margin white ciliate, apex bilobed, lobes hyaline, with a slender arista from the notch 1.3-3 times as long as the lobes. Lower lemma muticous, hyaline, lanceolate, obtuse, c. 0.67 times as long as the lower glume; upper lemma linear-lanceolate, hyaline, bifid, with a perfect scaberulous, $1.8-3 \mathrm{~cm}$ long awn. Anthers 3, c. $3.5 \mathrm{~mm}$ long, orange. Pedicel compressed, white ciliate, as long as the joint.

Distribution - E Thailand: Ubon Ratchathani, $2 \mathrm{~km} \mathrm{~S}$ of dam of Krong Chiam (Laegaard et al. 21837: L; AAU, QBG, n.v.; 21841: AAU), km. 75 on road 217, E of Warin Chamrap (Laegaard et al.21829: L; AAU, QBG, n.v.), S Cambodia, Popok Vil ('Poporkville'; T. Kira et al. 148: holo KYO; OSA, n.v.).

Habitat - On sloping sandstone with some seeping water, sandy old fields with scattered trees, 150-840 m altitude. 
Notes - This species was so far only known from the type from Cambodia.

Ohwi compared it to E. smitinandiana Bor, from which it differs by the more slender culms, glabrous ligule, single raceme, and lower glume with a deep groove with white hairs. Another '4-awned' species is E. milsumii Ridl. ('milsumi') from Selangor.

The pair of awns of the lower glume is apparently correlated with the presence of an awned upper glume: Bor (1960) mentioned E. bicornuta Bor,E.pallens (Hack.) Kuntze, and E. staintonii Bor with bidentate to bi-mucronulate lower glumes accompanied by an awned upper glume. This is so odd that a distinct section for these species might be contemplated.

\section{Germainia thorelii A. Camus}

Germainia thorelii A. Camus (1919) 287. - [Themeda capitata (Balansa \& Poitr.) Roberty var. thorelii Roberty (1960) 102, comb. inval.] - Type: Thorel s.n. (holo P; fragm. L).

Annual. Culms $0.25-0.5 \mathrm{~m}$ high, slender, distally branched. Sheaths glabrous to appressed pubescent, distally papillose. Ligule $0.4-1 \mathrm{~mm}$ long, glabrous. Blades linear-lanceolate, $1.5-2.5 \mathrm{~cm}$ by $2-3 \mathrm{~mm}$, papillose on both sides between incrassate margins, upper surface glabrous to appressed strigose. Peduncles 9-14 cm long, glabrous. Racemes 10-14 mm long (excl. awns), with 2 sessile and 1 pedicelled spikelet. Sessile spikelet: lower glume oblong, $9-14$ by $2-3 \mathrm{~mm}$, truncate with two lateral, caudate, 1-3.5 mm long teeth, glabrous, coriaceous, nerves 7-9, not anastomosing; upper glume linear-lanceolate, $10-12.5$ by $1.8-2 \mathrm{~mm}$, faintly 3 -nerved, apex obtuse, strigose. First lemma linear, $8-12$ by $0.8-1 \mathrm{~mm}, 1$-nerved. First palea linear, $8-9$ by 0.8-1 mm, obtuse. Upper lemma absent, or, when present, as the lower one. Upper palea as the lower one. Anthers c. $7 \mathrm{~mm}$ long. Pedicelled spikelet: callus c. $2 \mathrm{~mm}$ long, pungent, hairy. Glumes ovate-lanceolate, 3-nerved, apex obtuse to truncate, strigose; lower $6.5-7$ by $1-2 \mathrm{~mm}$; upper $5-6.5$ by $1-1.8 \mathrm{~mm}$. Lemma stipitiform, reduced to the flattened base of the awn. Awn $6.5-10.5 \mathrm{~cm}$ long. Palea rectangular, c. 3 by $2 \mathrm{~mm}$. Caryopsis c. $0.6 \mathrm{~mm}$ long.

Distribution - E Thailand: Ubon Ratchathani, c. $2 \mathrm{~km} \mathrm{~S}$ of dam in Krong Chiam (Laegaard et al.21834: L; AAU, QBG, n.v.), Laos: 'Me-Kong' (Thorel s.n.: P), perhaps also between Luang-Prabang and Vientiane (Joseph in herb. d'Alleizette 8022: L).

Habitat - Sloping sandstone with some seeping water, grasslands on limestone, 150-900 m altitude.

Notes - Especially curious is the papillose epidermis of sheaths and blades which appears to be unique for this species. In G.tenax (Balansa) Chai-Anan rows of inflated (and collapsed i.s.) cells are also present on the upper surface, but not as impressive as here.

As the only other collection so far known is in the d'Alleizette herbarium (L) it is not unlikely that it is part of the type. D'Alleizette is known to have gathered a large herbarium in the Paris Herbarium, often changing dates and localities to cover up.

A second collection of G. pilosa Chai-Anan was made by Esser (98-207) (L; A, AAU, BKF, CMU, K, M, n.v.) in the Doi Phu Phan National Park, like the type in Sakhon Nakhon Province, in a mixed deciduous forest along stream banks, on shallow moist sand above stone, at $800 \mathrm{~m}$ altitude. 
Parahyparrhenia laegaardii Veldk., spec. nov.

Parahyparrheniae siamensi similis, ex descriptione vaginis laminisque glabris, racemarum basibus inaequalibus, spiculis homogamis $4-7$, spiculis fertilibus desunt, vel 3 vel 4 paribus, glumae inferioris apice acuminato, gluma superiore 1-nervata, lemmate secundo c. 6 mm longo differt. - Typus: Laegaard et al. 21836 (holo L; AAU; QBG, n.v.), Ubon Ratchathani, c. $2 \mathrm{~km} \mathrm{~S}$ of dam of Krong Chiam.

Tufted perennial with a woody caudex, branching intra-vaginally at base. Culms simple, 0.7-0.95 m tall, internodes spongy inside, nodes glabrous. Cataphylls white setose. Leaf blades erecto-patent to reflexed, flat to involute, the lower disarticulating at base when old, $5.5-12.5 \mathrm{~cm}$ by $2-3.5 \mathrm{~mm}$, throat long-hairy inside, otherwise glabrous; upper 3 or 4 leaves reduced to $12-20 \mathrm{~cm}$ long sheaths with a vestigial blade. Racemes terminal, 1 or $2,3-7 \mathrm{~cm}$ long (excl. awns). Raceme bases subequal, that of the terminal raceme 6.5-9 mm long, glabrous. Joints linear, flattened, edges white-pilose, 3-4 $\mathrm{mm}$ long, c. 0.67 times as long as the sessile spikelet. Homogamous spikelets neuter to male, reduced to the joints with some vestigial scales, or solitary, or paired, 4-7 pairs. Upper spikelets sometimes absent on the lateral raceme, or 3 or 4 pairs in the terminal one. Sessile spikelets bisexual, only the upper floret present. Callus very oblique, $1.8-2.5$ $\mathrm{mm}$ long, hairs c. $0.5 \mathrm{~mm}$ long, white or purplish suffused. Lower glume 5-6.5 mm long (excl. callus), 3- (or 4-)nerved, apex acuminate, bidentate, teeth connected by scarious, easily torn tissue, distally pilose, otherwise glabrous, dorsally grooved; upper glume 6-6.5 mm long, 1-nerved, apex 2-lobed, awned from the sinus, awn false, straight, 7-8.5 mm long, slightly scaberulous. Lemma c. $6 \mathrm{~mm}$ long, apex scarious, bifid, awned from the sinus; awn perfect, column 25-27 mm long, puberulous, arista 20-25 mm long, scaberulous. Palea linear-lanceolate, scarious, c. 4 mm long. Lodicules not seen. Anthers 3, 2.8-3.7 mm long, yellow. Pedicels resembling the joints, 4-5 mm long. Pedicelled spikelet like the sessile ones, but smaller, neuter or male. Callus stipe-like, up to $2 \mathrm{~mm}$ long. Lower glume longitudinally grooved; upper glume awn c. $5 \mathrm{~mm}$ long. Lemma awn more or less straight, c. $8 \mathrm{~mm}$ long.

Distribution - E Thailand: Ubon Ratchathani, North and South of dam of Krong Chiam.

Habitat - Sloping sandstone with some water, 140-150 m altitude.

Notes - Parahyparrhenia A. Camus is a widely distributed but apparently rare genus with 2 species in Africa, 1 in India and now 3 in Thailand.

This new species is dedicated to Dr. S. Laegaard (AAU), co-collector of the type and many other interesting grasses when in Thailand in 2001.

Additional specimen: Laegaard et al. 21848 (AAU), c. $5 \mathrm{~km} \mathrm{~N}$ of dam.

\section{KEY TO THE SPECIES OF PARAHYPARRHENIA IN THAILAND}

1a. Homogamous spikelets absent or 4-7. Sessile spikelet: callus 1.8-3 mm long. Lower glume apex bidentate, dorsally grooved; upper glume apex with an arista 6-9 mm long. Upper lemma awn 40-52 mm long. Pedicelled spikelet lemma

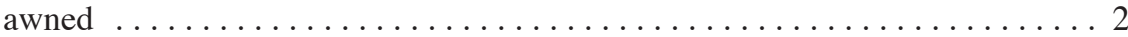

b. Homogamous spikelets 1 . Sessile spikelet: callus c. $1 \mathrm{~mm}$ long. Lower glume apex tridentate, dorsally not grooved; upper glume apex muticous. Upper lemma awn 
20-35 mm long. Pedicelled spikelet lemma awnless. - Blades glabrous. Sessile spikelet lower floret reduced to the lemma . . . . . . . . . 3.P. tridentata

2a. Blades glabrous. Homogamous spikelets 4-7. Sessile spikelet: lower glume apex bidentate, teeth connected by a scarious tissue. Lower floret absent. Pedicelled spikelet lemma awn c. $8 \mathrm{~mm}$ long $\ldots \ldots \ldots \ldots \ldots \ldots \ldots$. P. laegaardii

b. Blades pilose on both sides. Homogamous spikelets absent. Sessile spikelet: lower glume apex bimucronate, c. $1.5 \mathrm{~mm}$ long. Lower floret reduced to the lemma. Pedicelled spikelet lemma awn c. $3 \mathrm{~mm}$ long . . . . . . . 2. P. siamensis

\section{Sporobolus tenuissimus (Schrank) Kuntze}

Sporobolus tenuissimus (Mart. ex Schrank) Kuntze (1898) 369; Hack. (1904) 278, isonym. Panicum tenuissimum Mart. ex Schrank (1822) 26. - Aira tenuissima Spreng. (1825) 276. - Type: Martius s.n. (holo M).

Tufted annual. Culms up to $0.55 \mathrm{~m}$ high. Ligule a rim, $0.1-0.25 \mathrm{~mm}$ long, ciliolate. Blades homomorphous, folded, $8-18 \mathrm{~cm}$ by $1-3 \mathrm{~mm}$, margins smooth. Panicles effuse, up to 26 by $6 \mathrm{~cm}$, branches erecto-patent, solitary or fascicled, the lowermost few together, eglandular, lowest, longest branch 3-4 cm long. Spikelets $0.9-1.25 \mathrm{~mm}$ long, greenish to lead-coloured. Lower glumes $0.25-0.3 \mathrm{~mm}$ long, $0.2-0.37$ times as long as the spikelet. Upper glumes $0.4-0.75 \mathrm{~mm}$ long, $0.5-0.62$ times as long as the spikelet, acutish to obtuse. Lodicules c. $0.25 \mathrm{~mm}$ long. Anthers 3, 0.25-0.3 mm long. Seeds $0.5-0.7 \mathrm{~mm}$ long, turbinate, compressed, angular in transverse section. $2 \mathrm{n}=$ usually 12 , also 40 .

Distribution - Tropical S America, introduced elsewhere: S Andamans (Pt. Blair), Malesia; N Thailand: Chiang Mai (Laegaard et al.21652: AAU; QBG, n.v.), probably much more widespread.

Habitat - Disturbed places, e.g. roadsides, along fields, in Malesia often together with Eragrostis amabilis (L.) Wight \& Arn. ex Nees in Hook. \& Arn. (often called Eragrostis tenella (L.) P. Beauv. ex Roem. \& Schult.), $675 \mathrm{~m}$ altitude.

Uses - Cattle seem to disdain it. In N Sumatra grain used for stomach disorders. In Africa sometimes grown as an ornamental, but the specimens seen in Thailand, although with very gracile inflorescences, appear to be too small for such use.

Vernacular name - Tropical dropseed.

\section{REFERENCES}

Bor, N.L. 1960. The grasses of Burma, Ceylon, India and Pakistan: 154. Pergamon Press, Oxford, etc.

Buitenhuis, A.G. \& J.F. Veldkamp. 2001. Revision of Eremochloa (Gramineae-AndropogoneaeRottboelliinae). Blumea 46: 399-420.

Camus, A. 1919. Quelques espèces nouvelles des Graminées d'Asie. Bull. Mus. Hist. Nat. (Paris) 25: 287.

Hackel, E. 1904. Gramineae. In: R. Chodat \& E. Hassler, Plantae hasslerianae. Bull. Herb. Boissier II, 4: 278.

Kuntze, O. 1898. Revisio generum plantarum 3: 369. Felix, Leipzig, etc.

Ohwi, J. 1967. Four new species of Glumales from Southeast Asia. Acta Phytotax. Geobot. 22: 138. 
Phillips, S.M. 1995. Poaceae (Gramineae). In: I. Hedberg \& S. Edwards (eds.), Flora of Ethiopia and Eritrea 7: 122. National Herbarium, Addis Ababa / Department of Systematic Botany, Uppsala. Richard, A. 1851. Tentamen florae abyssincae ... 2: 425. Bertrand, Paris.

Roberty, G. 1960. Monographie systématique des Andropogonées du globe. Boissiera 9: 102.

Schrank, F. 1822. Bemerkungen über einige seltnere Pflanzen des k. botanischen Gartens zu München. Denkschr. Königl.-Baier. Bot. Ges. Regensburg 2: 26.

Sprengel, K. 1825. Systema vegetabilium 1: 276. Dieterich, Göttingen.

Steudel, E.G. 1854. Synopsis plantarum glumacearum. Pars I. Gramineae: 268. Metzler, Stuttgart.

Veldkamp, J.F. 2002. A revision of Eragrostis (Gramineae, Chloridoideae) in Malesia. Blumea 47: 187.

Veldkamp, J.F. \& S.M. Phillips. 2003. Tripogon (Gramineae) in Thailand. Blumea 48: 491-494. 